\title{
Was Phinehas a religious terrorist? In dialogue with Paul Cliteur
}

\begin{abstract}
The Dutch philosopher Paul Cliteur wrote a defence of secular thought in his recent book: "The secular outlook. In defence of moral and political secularism" (Chichester: WileyBlackwell, 2010). In this book he criticizes Christianity amongst other modern religions as inherently violent and as a danger to the liberal democracies and the human rights environments of our age. He is lead to this conclusion by an exegesis of several passages of Scripture. One of these passages is the story of Phinehas in Numbers 25:1-18. According to his exegesis Phinehas can be considered to be a biblical terrorist in the name of God, and he states that this conclusion can entice Christians to condone violence on religious grounds. This article evaluates Cliteur's use of Scripture from a Reformed Theological Ethical perspective and asks the question whether his conclusion is valid. This evaluation is done within the scope of the revelation of God in the book of nature, the written word and the incarnate word. From this perspective Cliteur's use of scripture in an a-historical way and without the evidence of the book of nature (natural law) and the revelation in Christ as the incarnate word can be termed as Biblicist, and thus as invalid.
\end{abstract}

\section{INTRODUCTION}

In his defence of moral and political secularism Cliteur (2010a:1) notes that the contemporary world is confronted with a relatively new phenomenon namely religious violence or, as he prefers to name it, religious terrorism:

"Governments are suddenly facing religious leaders who issue death sentences to writers, and they are struggling with the demands of religious minorities in the midst of their liberal democracies (Cliteur 2010a:105)."

At first sight it might seem that he has modern radical Islam in mind, but citing many examples he contends that the tendency towards violence is part and parcel of religious thinking and conduct as a whole. Religious terrorism is, according to Cliteur (2010a:105), justified by Scripture in certain cases. He is of the opinion that the inherent violent nature of religion manifests a contradiction between modern constitutional texts like the "Universal Declaration of Human Rights" and the "Holy Scripture" as handed down by the ancient religions of the book. His aim is to revisit the concept of secularism with the purpose of re-inventing secularism as the only discourse capable of establishing a peaceful environment within which various religions can function in a liberal democracy.

This aim is noble and cannot be questioned from a moderate religious perspective. However, the question is whether Cliteur judges Christianity fairly? Can his exegesis of the prominent passages of Scripture that he uses to prove his argument stand the test of sound scientific

1. Research professor at the Faculty of Theology (Potchefstroom Campus) of the Northwest University 
NGTT: Oopbron - http://ngtt.journals.ac.za

hermeneutical principles? One can even ask: Is Cliteur not making the same mistake in his exegesis of passages to prove his argument that Scripture justifies religious terrorism, as Biblicists make when they interpret Scripture a-historically and biblicistical? How sound and convincing is his use of Scripture?

This article aims to enter into dialogue with Cliteur on this issue. The central theoretical argument of the article is that Cliteur errs in his interpretation of Biblical texts by employing a proof text method to support his argument that Christianity is inherently violent. One example of such a proof text used in his argument will be discussed. This example represents the bulk of his criticism of Scripture. I am referring here to his analysis and application of the story of Phinehas in Numbers 25:1-18. First of all the history of Phinehas will be analysed and compared to the analysis that Cliteur presents. The meta-theory of the main principles regarding the use of Scripture in the Reformed tradition will be explicated in order to indicate the deficiencies of Cliteur's point of view. In conclusion, this model of biblical interpretation will be used to evaluate Cliteur's presentation of the Phinehas story.

\section{The Phinehas history}

The history of Phinehas took place after the Exodus of Israel, the people of the covenant, from Egypt according to the promise of God. While the people lived in Shittim on their way to the Promised Land they were enticed by the Moabites to take part in the religious practices of the people of Moab, who worshipped Ba'al Peor. This worship entailed sexual immorality with the daughters of Moab as a result of idol worshipping. Such an act was strictly forbidden by the first and the second commandments. The first commandment reads: "Thou shall have no other gods beside me" (Ex 20:2). Israelites were not supposed to devote their hearts to Yahweh as well as to other gods. The Shema calls the Israelites to love Yahweh with all their hearts, their souls and all their might (Douma, 1992:23). As the people of the covenant they had to be holier than the people of the land. This command to otherness is linked to the holiness of God that is expressed by the many ceremonial laws found in the book Leviticus. There are instructions regarding the holy places and the holy ceremonial actions, the offerings (Chapters 1-7), the chastity of people and the way animals should be treated (Chapters 11-15).

Furthermore, the seventh commandment forbids all forms of sexual immorality. The immoral actions of the Israelites were against the will of God. Leviticus 18 and 20 provides the regulations specifying the boundaries of permissible sexual relationships. According to these the Israelites would sin by engaging in sexual relations with the daughters of Moab. The people of Israel transgressed the law of God with their idolatry and sexual immorality. The death penalty was laid down for such grave sins against God such as idolatry (Ex 22:19; Lev 20:1-5; Dt 13:2-9; 17:27; Numbers 15:32-36) and also for abuses of sexual relations (Lev 20:10: Dt 22:22) (De Vaux, 1988:158). Offences in this regard would evoke the anger of God.

God instructed Moses to hang such men in public in front of the holy place. Such action would rescind the anger of God towards his people (Levine, 2000:288). The sentence was passed by the judges of Israel, probably those who were appointed by Moses over the Israelite divisions of thousands, hundreds, fifties and tens and who settled disputes among the Israelites (Cole, 2000:440). One man brought a Midianite woman into the gathering of the Israelites with the intention to engage in an immoral sexual relation with her. Phinehas killed this man and the woman to protect the honour of God. His action resulted in the rescinding of the anger of God and preventing the destruction of the Israelites. Phinehas was not punished for this act 
of murder. On the contrary, he was commended by God. God entered into a covenant with Phinehas and promised him a blessed future. For him and his descendants priesthood would be guaranteed.

God honoured Phinehas because he stood up for the honour of God in an act of atonement. By killing the adulterous couple he averted the judgement of God on the Israelites. Shortly after this event God instructed Moses to regard the Midianites as enemies and to destroy them because they acted with hostility towards the people of God and enticed them to worship Ba'al Peor. Two actions of God are noteworthy in this history:

- He commended Phinehas for the killing of the couple although the shedding of blood and the taking of a life was strictly forbidden in Old Testament ethics. The law against bloodshed was the foundation of all the other laws because it was a breach of the imago dei (Barth, 1961:116). God even rewarded Phinehas and his descendants with priesthood. An immoral act of murder is seemingly appraised by God and rewarded.

- God instructed Moses to exterminate the Midianites. Here again it seems that the instruction of God ran against his direct covenantal instruction in Genesis 9:5 and 6. In this passage He affirms the special status of the human in his creation. Created in His image, humans should mirror God's virtues in the world. His covenant, reaffirmed in these words, should be a "covenant of peace" (Wright, 2004:133). Therefore, all illegitimate shedding of human blood is forbidden.

\section{Cliteur's perspective on the Phinehas history}

In his defence of a secular outlook Cliteur refers to this history of Phinehas to conclude that Scripture condones what he terms "biblical terrorism" and violence perpetrated by citizens themselves. For him this story is not only an exciting, though gruesome story, but interesting because of the Lord's reaction. The Lord did not reprimand Phinehas, but rewarded him. He is of the opinion that while Moses flouted the authority of God by killing only the people guilty of idolatry and not all the chiefs as God commanded, Phinehas did what God commanded. Apparently, Phinehas' religious zeal is more appreciated by God than Moses' cautious way of dealing with the matter (Cliteur, 2010a:107).

This stance can have grave consequences. It is even likely that it would have grave consequences. According to Cliteur God's rewarding of Phinehas can be seen as substantial encouragement to those who claim special knowledge of God's will and who are prepared to perpetuate violence in defiance of the traditional political leaders of the state. Phinehas can be seen as the archetypical religious terrorist because he is prepared, on religious grounds, to use violence against citizens of the state, thereby violating the law of the state and defying legitimate authority. Modern-day religious terrorists act according to the same pattern.

Cliteur (2010a:107) continues:

\footnotetext{
"It is clear that this attitude and the whole worldview connected with it is hard to reconcile with modern freedom of religion, freedom of worship, freedom of speech, freedom of conscience, free inquiry and other fundamental rights ingrained in the concept of a liberal democracy."
}

The story proves that religion in its organised as well as its unorganised manifestations poses challenges to modern liberal democracies. 
NGTT: Oopbron - http://ngtt.journals.ac.za

His interpretation of the Phinehas story leads him to far-reaching conclusions. Cliteur argues that the action taken by Phinehas can be seen as a justification of violence when the honour of God is at stake and that this story is proof that religion is essentially a danger to democracy and fundamental human rights. He laments the violent nature of religion that does not recoil from intimidation, threats, murder and sedition. Today such violent kinds of religions are reappearing (Cliteur 2010b:235). These conclusions can be debated, but the main question remains: Is his interpretation of Scripture valid? Can a historical event in the Old Testament be interpreted in such a prescriptive way in order to formulate moral directives for Christian conduct today? To answer this crucial question attention should be paid to the way Scripture ought to be interpreted in the effort to understand the relevance of historical material for modern-day moral conduct.

\section{Hermeneutical principles}

In his article on the relevance of Old Testament ethics Carroll (2011:561) explains the various epistemological paradigms that are currently employed to understand the meaning of the Old Testament for Christian ethics. He gives a resume of these and explains the value and problems provided by each of these paradigms of interpretation. He concludes that the fact that Scripture is both literature and Scripture adds immeasurable weight to the process of reading, and he discusses certain examples. What is a clear pattern of reasoning in all these paradigms is that a literal reading of the Old Testament does not bring the Old Testament reader to the core meaning of ethical norms for present day conduct. A clear epistemology is necessary. Cliteur does not take this important prerequisite seriously and approaches the Phinehas story in a very a-historical and naïve way. What is important in Carroll's account is his reference to the canonical approach and the resurgence of a theological interpretation of Scripture (Carroll, 2011:565). This methodology endeavours to approach the part (text) from the perspective of the whole, such as the socio-historical and the biblical context. This article follows this line of thought and will use the concept of divine revelation as its point of departure.

\subsection{Revelation}

The hermeneutical angle of approach includes the presupposition that the Christian religion is a religion emanating from the self-revelation of God to human beings. It is consequently essential to explain what is meant by revelation and what the characteristics of this revelation are. Such an explanation is important in the exposition of Christian thinking, as well as the evaluation of secular critique, because both Christian ethics and secular critiques can err in this regard. A good example of such an erroneous use of Scripture is the view of divine revelation in the (emerging) Christian fundamentalism. According to this version of fundamentalism the revelation of God is embedded in Scripture, and especially in a literal and a-historical reading of the Biblical text. This view of Scripture is also called Biblicism. According to Ritschl (1999:255) this term is commonly used to denote a particular way of dealing with Scripture, especially the expectation that it can be transposed directly into modern thought and forms or lifestyles. In his thorough study on the ethical meaning of the Ten Commandments in modern society, Douma (1992:363) also warns against the dangers of Biblicism for the understanding and application of Christian ethics. By Biblicism he means appeals to Scripture that use the biblical texts in an atomistic (isolated) way by lifting them out of their immediate contexts or out of the whole context of Scripture. Biblicism is characterized by its neglect of the difference in contexts between then (the time in which the texts being cited were written) and now. 
With regard to Christian ethics the literal Bible is seen as the only source for Christian ethical reflection. This use of Scripture evokes valid criticism against Christian morality from a secular perspective, for example the issue of the violence in the Old Testament as a result of divine commands.

Wogaman (1993:278) pleads for a more open and deeper use of Scripture that commits Christian ethics to a theological reflection that is more than just historical exegesis. The theologian must employ Scripture tradition, experience and reason. What Wogaman proposes seems to be adequately expressed in the classic Reformed creed, the Belgic Confession. According to this classic confession, God reveals himself in two ways. The article reads:

"We know Him by two means: first, by the creation, preservation and government of the universe; which is before our eyes a most elegant book, wherein all creatures, great and small, are as so many characters leading us to contemplate the invisible things of God namely, His eternal power and divinity, as the apostle Paul said (Rom. 1:20). All things are sufficient to convince men, and leave them without excuse. Secondly, He makes Himself more clearly and fully known by His divine Word, that is to say, as far as is necessary for us to know in this life, to His glory and our salvation" (Beeke et. al. , 1999:8)."

This article of the Belgic Confession is based on the Institutes of Calvin (Institutes, l:6:1:26)

In view of John 1:1 and the contents of this confession one can conclude that the revelation of God has three manifestations, namely the creational Word (the book of nature), the written word (Scripture), and the incarnate word (Jesus Christ). All three these manifestations of the revelation of God are necessary for a Christian ethical epistemology in the face of the current secular outlook. It is therefore essential to focus on each of these shortly.

\subsection{The "book of nature" (creational gifts or natural law)}

The revelation of God in the book of nature entails that God has bestowed on every human creature a sense of morality. These gifts were called natural law in the early Reformation (Witte, 2007:156). A more preferable term is "creational gifts", which entail gifts that were given by God to all people, not to bring about their own salvation, but to preserve law and order in human society. This idea was prominent among Reformed theologians in the Reformation (Grabill, 2006:175). Therefore any person can formulate good norms and live by good moral norms and every government, irrespective of persuasion, can make a good law. Moral views depend on deeply held notions of the good. Everyone draws on such sources (Taylor, 2007:405).

The recognition of natural law or creational gifts in the cultivation of a Christian Reformed epistemology is important because it safeguards Christian Ethics from an exclusive claim on moral authority and Biblicism. In a recent study Grabill (2006:3) discusses the new interest in the concept of natural law in Protestant ethics. Though the Barthian school lead a protest against natural law theory during the 20th century in response to the theological justification of national socialism in Germany by the Reichskirche, a new interest in this concept has grown in recent times, especially as a source of Christian ethical moral thought (see Brunner \& Barth, 1946:71). Christian ethics can draw from natural law (creational gifts) in a secular environment. For example, Christian ethics can draw moral norms from the contemporary human rights discourse, and for this reason alone religious terrorism should be rejected in the circle of Christianity. In this respect the value of natural law in the Christian ethical discourse about bio-ethics and eco-ethics also comes to mind. However, the use of natural law in the Christian 
NGTT: Oopbron - http://ngtt.journals.ac.za

ethical approach must conform to one condition. Such a morality should not run against the thrust of the other sources of Christian moral thinking, namely the written word and the incarnate word. In this respect Barth's criticism of the use of natural law is relevant. Natural law cannot supersede the great commandment and the biblical message of reconciliation in order to provide a religious and moral backbone for ideologies. This erroneous use of natural law was evident in the Christian justification of national socialism in Germany in the 1930's and apartheid in South Africa in the 1970's. The morals derived from natural law must function within the ambit of the great commandment, which is the deepest foundation of Christian ethics.

\subsection{The written word}

In the use of the written word (Scripture) the utilization of "proof texts" is always tempting because it is an easy way to come to terms with certain obvious moral issues and to give credibility to a certain point of view by claiming the authority of Scripture. This is exactly what Cliteur does with his interpretation of the Phinehas story. The classic Reformed perspective on the interpretation of Scripture can be found in the explanation of the Larger Westminster Catechism (1648). This historical document of Reformed and Presbyterian churches provides a guideline for how Scripture should be interpreted (Beeke et. el., 1999:11). According to this confession the Scriptures manifest themselves to be the Scripture by inter alia, the consent of all the parts (Ac. 10:43; 26:22) and the scope of the whole.

In the classic Reformed view Scripture is seen as a book containing a continuous message according to various continuous themes. It is the message of God's renewal of the fallen world in Jesus Christ and the restoration of His relation with humanity. Various underlying themes unfold this main message, such as God's election of his people, the covenant, judgment and grace, reconciliation, transience and resurrection. The main theme is the kingship of God, which means God's rule over creation and his entering into a personal relationship (Covenant) with mankind. Bright (1973:7) echoes this conviction with his well-known statement that the concept of the kingdom of God involves in a sense the total message of Scripture. In spite of the fact that Bright's emphasis on the kingdom as the only main thread in Scripture can be questioned, the fact is that he clearly proves that Scripture should be approached as a source with a continuous message, and that individual texts should be read against this background.

Obviously Scripture was not written in a linear, historical or a logic way. There are repetitions of stories, for example in the books of Kings and Chronicles. There are four gospels, and it seems that the apostles deal with certain issues repeatedly and even in seemingly conflicting ways. No account is given of certain phases in the history of Israel. However, it is not the intention of Scripture to present a historical survey. It deals with the themes important to understand the whole message. Some accounts will approach a topic from a different angle than others. Certain writers wrote for different audiences. There are various literary genres. However, the main message is consistent and the various parts are in harmony when the parts are interpreted in light of the whole. Seemingly conflicting parts can be reconciled when they are viewed against the background of the whole message of Scripture.

The justification of the authority of Scripture in the "scope of the whole", flows from the acceptance of the "consent of all the parts". Scripture has authority as a developing organism containing a basic message by way of various sub-themes. That is the reason why the "scope of the whole" is presented as an argument in favour of the divine authority of Scripture. This view 
has severe implications for biblical interpretation. Scripture cannot be interpreted without taking cognizance of the scope of the whole.

This message is not a chronological story, but a story in a revelation-historical sense. Some scholars speak of salvation-history. The history of revelation is the unfolding of the creation, renewal, up-building and future of God's kingdom. Understanding this story requires exegetical and theological reflection in order to do justice to the biblical text. Kaiser and Silva (1994:193) point out that the exegetical part of the interpretative process examines the grammatical, historical and literary aspects of the texts. Once these tasks have been concluded, they need to be related to the overall thought of the individual book being studied and to the whole canon of Scripture. In other words, biblical texts can be interpreted by means of an exegetical process, taking into account the grammar of the original languages and the cultural background of the particular text, but eventually they must be reconciled in view of the whole story. The "scope of the whole" should be involved when the Phinehas story comes to mind. Then it is clear that the action of Phinehas cannot be seen as a model of Christian conduct to defend religion, because his violence runs against the great commandment of love (also for the enemy Mt 5:43-48) which is embedded in the total message of the written word.

\subsection{The incarnate word}

Thirdly, Christian ethics draw on the incarnate word, and that is Jesus Christ Himself (Jn. 1: 1). God revealed Himself in the person and work of Jesus Christ. Waters (2010:5) calls the incarnation of the Word of God the formative moment of the Christian moral life. He continues to say that in this act God completes the reconciliation with creation and its creatures that were initiated in the covenant with Israel. Christ indicates the "way of his father" in his teachings and conduct. He is portrayed as the example of true Christian morality. Christians should follow in the footsteps of Christ. Filled with the mind of Christ they should imitate his attitude (Phil 2:5-11), which is an attitude of self-sacrifice (kenosis), servant hood, humility and obedience to God (see Martin, 1997:171; Schrenck, 1984:193 \&Vorster, 2007:17) Berquist (2011:401) says that the incarnation of God in Jesus Christ is usually understood as a requirement and hallmark of true Christian faith.

Many noble principles in the Christian moral theory flow from the teachings and conduct of the incarnate word. In addition to his example of self-sacrifice, servant hood, humility and obedience to God, Christ teaches Christians the way of repentance, forgiveness, reconciliation and restoration. He reveals himself as the custodian of peace and non-violence. Furthermore, incarnation shows us an embodied God who resists acts that defile, devalue or damage human bodies (Berquist, 2011:402). Following in his footsteps, Christians should promote peace and bring hope and heal humanity. They have to be the custodians for justice for the poor and the oppressed and the watchdogs of the powers of the day. The morals of the incarnate word give new meaning to all other Christian ethical principles. Whatever morals a Christian teacher derives from the "book of creation" and the written word may never contradict the morals taught by the incarnate word, Jesus Christ. He gives true meaning to all other Christian moral teachings.

In the light of this explanation of the revelation of God as the source of biblical ethics and the conditions set for the understanding of Christian morality, the criticism of Cliteur against Christian morality can be addressed. As said earlier, his own hermeneutical approach is Biblicist because he loses sight of the "consent of the parts" and the "scope of the whole". Moreover, he 
NGTT: Oopbron - http://ngtt.journals.ac.za

loses sight of God's revelation in the incarnate word and the centrality of the moral example of Jesus Christ as the incarnate word. Read within the hermeneutical paradigm discussed above, the moral implications of the Phinehas story will be quite different from Cliteur's perspective.

\section{Phinehas Revisited}

What is the essential moral meaning of the story of Phinehas? Is it all about the justification of religious violence or biblical terrorism as Cliteur concludes? To answer the question the difference between prescriptive passages and descriptive passages in Scripture should be taken into account. Sometimes Scripture describes historical events and customs, for example the fact that the Israelites had slaves. However, the fact that Scripture mentions the practise of slavery among Israelites must not be seen as a justification for slavery. Then a descriptive part is elevated to a moral norm. This was indeed the case in churches for many centuries until Christians started to question slavery on the basis of the principle of the human dignity founded in the concept of the imago dei. (Ramsey, 1993:259; see also Berkouwer (1957:121).

Also, the fact that Scripture mentions the existence of many nations in its historical surveys cannot be seen as a prescription that ethnic identities should develop separately. This description cannot be used as a justification for apartheid between races and nations as the ideology has indeed emerged in South Africa. The earlier justification of slavery and the recent justification of apartheid on biblical grounds are but two of the outstanding examples of the distortions that can originate when descriptive passages are interpreted as prescriptive passages. It is of the utmost importance that the prescriptive parts must be mined out of the context where they are not explicitly or clearly indicated. This is also the case with the Phinehas story.

Numbers 25:1-18 deals essentially with the protection of the honour of God as a holy God that should be worshipped as such. The holiness of God is a constant theme in the Old Testament and this holiness comes to the fore in the covenantal people's belonging to God and being consecration to him (Joosten, 1996:125). The underlying theological message is that the holiness of God should spill over in the call to holiness of the people of God. Holiness relates to the right ordering of social relationships, that is, the practice of neighbourly righteousness (Brueggemann, 2002:99). The Israelite lifestyle and conduct should reflect His holiness and should be manifested in love, peace and justice for the poor. This link between the holiness of God and the holiness of the people is expressed in the Holiness Code of Lev 19:2. The people should be holy, not only in the cultic sense, but in their culture (Brueggemann, 1997:290). An unholy and disobedient life debases and profanes God's name in the eyes of the nations. The history of the Kings as portrayed in the Bible books Kings and Chronicles testifies to the importance of the respect for God as a holy God. When the people stray in unholiness and disobedience they are punished by God. The action of Phinehas should be evaluated in this context. He defended the honour and holiness of God and thus also the instruction to the people of the covenant to act according to the morality of the covenant and to seek the wellbeing of the community. The moral of the story of Numbers 25:1-18 is not Phinehas' killing of the two people, but his obedience to God and his protection of the holiness of God, which should manifest in the holiness of the people of the covenant. Cliteur's exposition of this history misses this point because he neglects the context of this history within the broader framework of the holiness code.

Another very important Old Testament instruction should be attended to when dealing with 
this passage. This instruction is the instruction in Genesis 9: 6: "Whoever sheds the blood of man, by man shall his blood be shed, for in the image of God has God made man". Respect for the sanctity of human life is also a major theme that runs through the biblical revelation. Human life is important because humans are created in the image of God and received from God the "breath of life". The Hebrew word used for the "breath of life" is ruach and the word used for living being is nephesh. The ruach is more than breath in a biological sense. It indicates life that comes from God and contains the spirit of God (Preuss, 1991:161). These are the reasons why God forbids manslaughter and why preservation of life is so important in the Old Testament laws (Barth, 1961:344). God reiterated his concern for human life in the sixth commandment. To argue that God condoned the murders committed by Phinehas with tacit consent is to neglect the whole Old Testament concept of the sanctity of human life, and it therefore also runs against Christian anthropology.

In the last instance the moral codes of Scripture must correlate with everything Jesus Christ as the incarnate word stood for. He came to reconcile the human being with God and to present the full meaning of the law. The full meaning of the law is the love of God and the neighbour - even the enemy. The whole Christology of Scripture is embedded in love, peace and reconciliation and any moral code running against it is devoid of meaning and application. The violence used by Phinehas to defend the honour of God contradicts the Christology and can therefore not be elevated to a prescriptive norm for Christians to apply in inter-human relationships. Cliteur does not take cognisance of this highly important rule in the interpretation of Scripture.

\section{Conclusion}

In his defence of the secular outlook Cliteur attempts to make a case for the violent nature of Christianity. However, his use of Scripture is erroneous and has the ring of robust Biblicism. He does not apply the most basic scientific hermeneutical rule, namely that Scripture must be read as the history of salvation that flows into the great commandment of love. No violence even in the name of God can be justified in view of this message. Therefore his critique on Christianity as a religion of violence that condones biblical terrorism must be regarded as invalid.

\section{BiBLIOGRAPHY}

BARTH, K. 1961. Church Dogmatics. Volume III. The doctrine of creation. Part 4. Edinburgh: T \& T Clark BEEKE, J. R. et. al. 1999. Harmony of the Reformed Confessions. Grand Rapids: Baker Books.

BERKHOUWER, G.C. 1957. De mens het beeld Gods. Kampen: Kok,

BERQUIST, J.L. 2011. Incarnation. (In Green J.B. ed. Dictionary of Scripture and Ethics.) Grand Rapids: Baker Books.

BIRCH; B.C.; BRUEGGEMANN, B; FRETHEIM, T.E. \&. PETERSEN, D.L. 2005. A Theological Introduction the Old Testament. Nashville: Abington.

BRIGHT, J. 1973. The kingdom of God. The biblical concept and its meaning for the church. New York: Abingdon Press.

BRUEGGEMANN, W. 1997. Theology of the Old Testament, Testimony, Dispute, Advocacy. Minneapolis: Fortress Press.

BRUEGGEMANN, W. 2002. Reverberations of faith. London: Westminster John Knox.

BRUNNER, E. \& BARTH, K. 1946. Natural Theology. London: Geoffrey Bles.

CALVIN, J. 2008. Institutes of the Christian Religion. Peabody: Hendriksen (Translated by H. Beveridge).

CARROLL, M.D. 2011. Old Testament Ethics. (In Green, J.B. et al. Dictionary of Scripture and Ethics Grand Rapids: Baker. p.561-565). 
NGTT: Oopbron - http://ngtt.journals.ac.za

CLITEUR, P 2010a. The secular outlook. In defence of moral and political secularism. Chichester: WileyBlackwell.

CLITEUR, P. 2010b. Religion and violence. (In VAN DE BEEK, A, VAN DEN BORGHT, E.A.G.J. \& VERMEULEN, P.B. Freedom of religion. Leiden: Brill. p.235-250.)

COLE, R.D. 2000. Numbers. New International Version. The American commentary. An exegetical and theological exposition of Holy Scripture. Nashville: Broadman \& Holman.

DE VAUX, R. 1988. Ancient Israel. Its life and institutions. London: Darton, Longman \& Todd.

DOUMA, J. 1992. The Ten Commandments. Manual for Christian Life. Philipsburg: P\&R.

GRABILL, S.J. 2006. Rediscovering Natural Law in Reformed Theological Ethics. Grand Rapids: Eerdmans.

JOOSTEN, J. 1996. An exegetical study of the ideational framework of the law in Leviticus 17 - 26. Leiden: Brill.

KAISER W.C \& SILVA, M 1994. An Introduction to Biblical Hermeneutics. The search for meaning. Grand Rapids: Zondervan.

LEVINE, B. A. 2000. Numbers 21 - 36. A new Translation with introduction and commentary. New York: Double Day.

MARTIN, R.P. 1997. A hymn of Christ. Downers Grove: Inter-Varsity Press

PREUSS, H.D. 1991. Old Testament Theology, Volume 1. Louisville: Westminster.

RAMSEY, P. 1993. Basic Christian ethics. Louisville: Kentucky.

RITSCHL, D. 1999. Biblicism (In FAHLBUSCH, E. et al. The Encyclopaedia of Christianity. Volume 1. Leiden: Brill. p.255-256.)

SCHRENCK, W. J. 1984. Die Philliper Briefe des Paulus. Stuttgart: Kohlhammer.

TAYLOR, C. 2007. A secular age. Cambridge: The Belknap Press of Harvard University Press.

VORSTER, J.M. 2007. Christian attitude in the South African Liberal Democracy. Potchefstroom:

Potchefstroom Theological Publications.

WATERS, B. 2010. The incarnation and Christian moral life (In LERON SHULTZ, F. \& WATERS, B. eds. Christology and ethics. Grand Rapids: Eerdmans.)

WITTE, J. 2007. The Reformation of rights. Law, religion, and human rights in early modern Calvinism. Cambridge: University Press.

WOGAMAN, J. P. Christian Ethics. A historical introduction. Louisville: Westminster John Knox.

WRIGHT, C.J.H. 2004. Old Testament ethics for the people of God. Leicester: Inter-Varsity Press.

\section{KEY WORDS}

Hermeneutics

Revelation

Phinehas

Incarnate Word

Secularism

Secular

\section{TREFWOORDE}

Hermeneutiek

Openbaring

Phineas

Menswording van Christus

Sekularisme

Sekulêr

\section{Contact Details}

Vorster, J.M. (Koos)

Research professor in Theology

North-West University

South Africa

Koos.Vorster@nwu.ac.za 